\title{
Protein utilization during energy undernutrition in sheep sustained by intragastric infusion: effects of protein infusion level, with or without sub-maintenance amounts of energy from volatile fatty acids, on energy and protein metabolism
}

\author{
BY S. A. CHOWDHURY ${ }^{1}$, E. R. ØRSKOV ${ }^{1} \dagger$, F. D. DeB. HOVELL ${ }^{1}$, J. R. SCAIFE ${ }^{2}$ \\ AND G. MOLLISON ${ }^{1}$ \\ ${ }^{1}$ Rowett Research Institute, Bucksbum, Aberdeen AB21 9SB \\ ${ }^{2}$ School of Agriculture, University of Aberdeen, 581 King Street, Aberdeen AB9 IUD
}

(Received 15 June 1995 - Revised 17 June 1996 - Accepted 17 July 1996)

\begin{abstract}
Utilization of endogenous and exogenous energy for protein accretion during energy undernutrition has been studied. Nine lambs nourished by intragastric infusion were given either progressively increasing or decreasing amounts of casein-N up to $2550 \mathrm{mg} / \mathrm{kg}$ metabolic weight $\left(W^{0.75}\right)$, with or without $250 \mathrm{~kJ} / \mathrm{kg} \mathrm{W}^{0.75}$ of volatile fatty acids daily. Energy balance (respiration calorimetry) and $\mathrm{N}$ balance were measured. While all experimental animals were in negative energy balance, $\mathbf{N}$ balance increased curve-linearly with the increase in casein- $N$ infusion and attained positive $\mathbf{N}$ balance. Endogenous energy (presumably body fat) was found to meet the energy needs for protein accretion during energy undernutrition. It is concluded that body fat can be effectively utilized to support lean-tissue growth during energy undernutrition, so that the classical nutritional concept of dietary energy:protein ratio is only meaningful when both endogenous and exogenous energy are considered.
\end{abstract}

Intragastric infusion: Energy undernutrition: Protein utilization: Fat mobilization

Due to the interdependence of fermentable energy intake and microbial protein production (Agricultural Research Council, 1980), the depositions of body fat and protein are normally found to be positively correlated in fed animals (Leat, 1983). The technique of intragastric infusion, in which all nutrients are infused (volatile fatty acids (VFA) into the rumen, and protein, minerals and vitamins into the abomasum; Ørskov et al. 1979), has enabled the supplies of energy (VFA) and protein to be varied independently. Thus, Ørskov et al. (1983) and Hovell et al. (1983) were able to test whether otherwise fasted animals would metabolize infused protein as a source of energy or utilize it to meet the estimated protein requirement for tissue maintenance. They showed that dairy cows, steers and lambs did not oxidize the supplied protein as a source of maintenance energy but rather retained it to achieve $\mathrm{N}$ equilibrium. This was made possible by the mobilization of endogenous energy (presumably body fat) to fuel protein accretion (Ørskov \& Hovell, 1986). Using the intragastric infusion technique, steers were given protein ranging from zero to four times that of maintenance requirement with no other source of energy; the animals not only attained positive $\mathrm{N}$ balance at the expense of body fat, but showed rapid body-weight gain (Chowdhury et al. 1990). This implies that with normally-fed animals the effect of dietary 
energy on $\mathrm{N}$ retention could be as much due to the synthesis of additional microbial protein as to a simple energy effect. This concept differs from the model proposed by Balch (1967) and subsequently adopted by the Agricultural Research Council (1980) that N retention is a quadratic function of both energy and protein intake, which predicts that at very high protein and low energy intakes, $\mathrm{N}$ retention could be negative. To distinguish between these concepts the experiment reported here was designed to study the effect of supplying either zero or sub-maintenance amounts of energy (as VFA) together with different levels of protein on the $\mathrm{N}$ and energy balance of growing lambs.

\section{MATERIALS AND METHODS}

\section{Animals and their management}

Eight cross-bred (Suffolk $\times$ Grey Face or Blue-Du-Maine) wether lambs aged 8-12 months, having a mean live weight of 49 (SD 5.2) $\mathrm{kg}$ were used. They had each been fitted with a rumen cannula and an abomasal catheter as described by Ørskov et al. (1979). Before the experiment, the animals were accustomed to a closed-circuit respiration chamber for 2 weeks, during which they received a general purpose (GP) diet (hayconcentrates, 1:1, w/w) ad libitum. Overnight-fasted live weight was recorded at the onset of the trial and was used to calculate the subsequent levels of infusion.

\section{Intragastric infusion}

The technique for intragastric infusion, the composition of the infusates and the control of the infusion were as described by Ørskov et al. (1979) and MacLeod et al. (1982) except that the vitamin mixture was amended according to the Agricultural Research Council's (1980) recommendation (see Chowdhury, 1992). The volumes infused were as reported by Hovell et al. (1983). Energy was supplied by a mixture of VFA containing acetic 0.65 , propionic 0.25 and butyric acid $0 \cdot 10$, as molar proportions. The diluted VFA mixture and buffer solution containing $\mathrm{NaHCO}_{3}$ and $\mathrm{KHCO}_{3}$ were infused separately into the rumen. Vitamins and linoleic acid were included in the casein solution, and trace minerals were injected into the abomasal catheter once daily. Rumen $\mathrm{pH}$ and osmotic pressure were measured in the morning and afternoon.

\section{Experimental protocol}

The experiment was conducted with two levels of energy, 0 or $250 \mathrm{~kJ} / \mathrm{kg}$ metabolic weight $\left(\mathrm{W}^{0.75}\right)$ daily of VFA, and different levels of protein. To see whether energy and $\mathrm{N}$ responses were affected by the direction of nutrient supply, protein was supplied in either progressively increasing or decreasing amounts. This gave four treatment groups, A, B, C and D. The details are shown in Table 1. Eight animals were randomly assigned to four treatments having two animals in each group. The experimental animals were changed from the GP diet to total intragastric infusion over $7 \mathrm{~d}$. The infusion of nutrients was stepped up by increasing the levels of energy and protein infused until the maintenance level was achieved on the 7th day. At maintenance the level of infusion was $450 \mathrm{~kJ} \mathrm{VFA} /$ $\mathrm{kg} \mathrm{W}^{0.75}$ and $500 \mathrm{mg}$ casein-N/kg $\mathrm{W}^{0.75}$ daily, which continued for $4 \mathrm{~d}$. Once the infusion regimen was established, the casein supply was either abruptly removed and then progressively increased to provide $250,500,750,1350,1950$ and $2550 \mathrm{mg} \mathrm{N} / \mathrm{kg} \mathrm{W}^{0.75}$ daily for periods of $4 \mathrm{~d}$, or built up to $2500 \mathrm{mg} / \mathrm{kg} \mathrm{W}^{0.75}$ daily over $8 \mathrm{~d}$ and then reduced 
Table 1. The experimental protocol. All values are expressed on a metabolic body weight $\left(\mathrm{kg} \mathrm{W}^{0.75}\right)$ basis

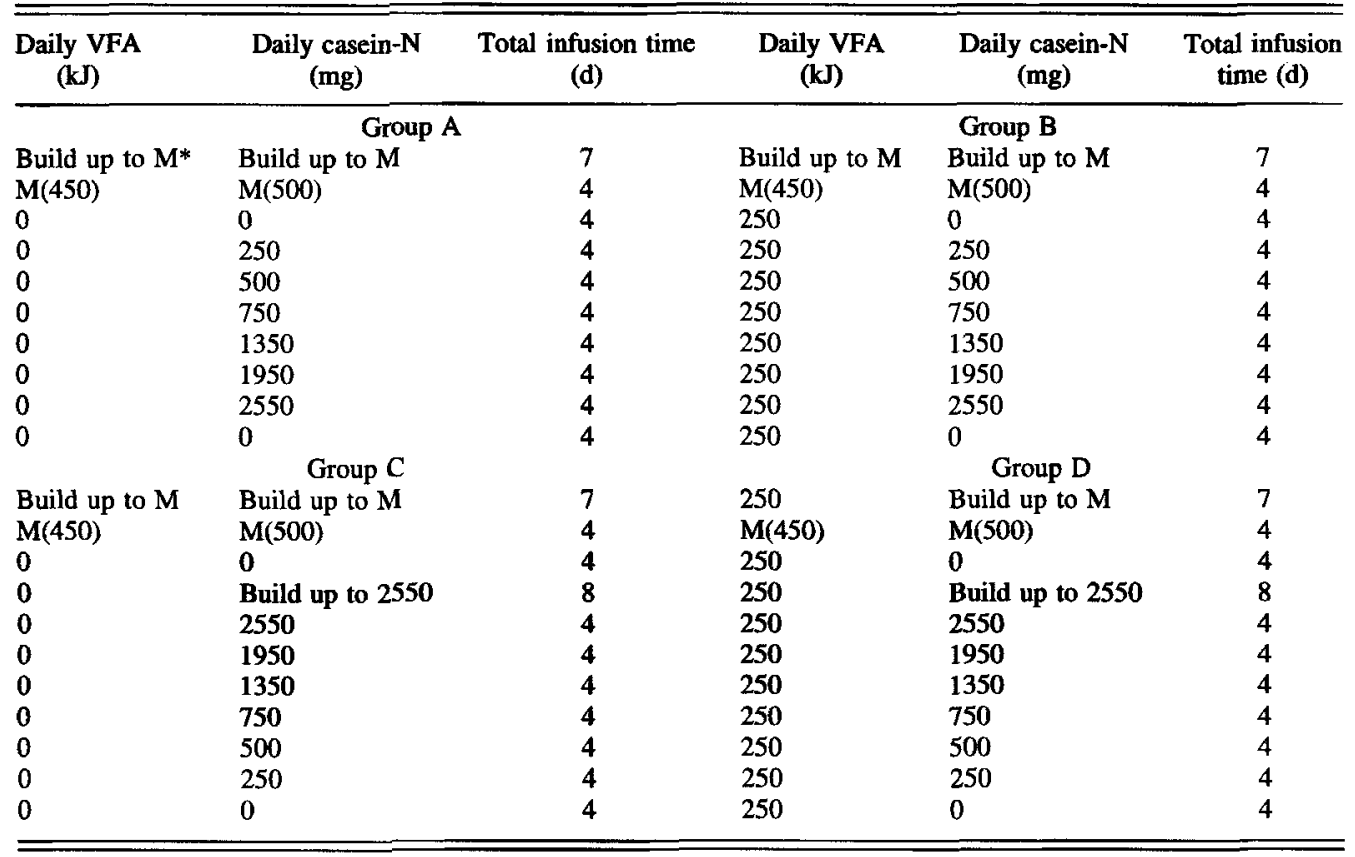

VFA, volatile fatty acids; $M$, maintenance.

* Daily maintenance level of infusion for both protein $\mathrm{N}\left(500 \mathrm{mg} / \mathrm{kg} \mathrm{W} \mathrm{W}^{0.75}\right)$ and energy $\left(450 \mathrm{~kJ} / \mathrm{kg} \mathrm{W}^{0.75}\right)\left(\varnothing_{\text {rskov } \&}\right.$ Hovell, 1986).

by the same steps in the reverse order. Four animals (two from group A and two from group C) received only protein, the other four (two from group B and two from group D) received in addition $250 \mathrm{~kJ} / \mathrm{kg} \mathrm{W}^{0.75}$ daily of energy from VFA.

\section{Heat measurement}

Heat production was estimated from $24 \mathrm{~h} \mathrm{O}_{2}$ consumption, measured in a closed-circuit respiration chamber, taking the mean heat equivalent of $\mathrm{O}_{2}$ for the oxidation of VFA, protein and fat to be $19.55 \mathrm{~kJ} / 1$ (Chowdhury, 1992). Postural contributions to heat production were removed from the total heat production (see Lobley, 1990) by excluding the energy cost of standing ( $25 \mathrm{~J} / \mathrm{kg}$ live weight per min; Brockway, 1987).

\section{Estimation of energy and nitrogen balances}

The $\mathrm{N}$ balance was calculated from the differences between the casein- $\mathrm{N}$ infused and $\mathrm{N}$ excreted in the faeces and urine. Energy balance was calculated from the difference between the corrected (for standing) heat production and energy supply from VFA and casein. The contribution of casein energy to the effect of the VFA infusion on energy balance was calculated as the difference in total $\mathrm{N}$ excretion between fasting (when no VFA or casein was infused to the animals of groups $A$ and $C$ ) or basal (when animals of groups $B$ and D were given $250 \mathrm{~kJ}$ VFA with no casein) $\mathrm{N}$ excretion (g/d) multiplied by 
132 ( $\mathrm{kJ}$ metabolizable energy (ME) in $1 \mathrm{~g}$ of casein- $\mathrm{N}$; Livesey, 1984). $\mathrm{N}$ balance was measured from the beginning of the maintenance level of infusion to the end of the trial, while energy balance was measured during days 2,3 and 4 at each level of infusion. As there were only four respiration chambers, energy and $\mathrm{N}$ balance measurements were made on four animals in four treatments at a given time followed by measuring the same on the other four animals. During the whole experimental period, animals were housed in calorimeters.

\section{Body composition}

At the end of the experiment the animals were killed and the whole body was minced. Freeze dried sub-samples were analysed for DM, fat and $\mathrm{N}$. The initial body composition of each animal was then calculated from the measured $\mathrm{N}$ and energy exchanges.

\section{Chemical analysis}

The DM contents of faeces and carcass were determined by oven-drying at $101^{\circ}$ for $48 \mathrm{~h}$. The total $\mathrm{N}$ in faeces, urine and carcass was determined with an auto-analyser according to the automated Kjeldahl procedure of Davidson et al. (1970) after hydrolysis. The fat content of the carcass was determined by the methanol-chloroform method of Atkinson et al. (1972). Urinary urea- $\mathrm{N}$ was determined according to the method of Technicon Instruments (1967).

\section{RESULTS}

\section{Animal health}

The animals remained in good health, although some showed abnormal jaw movements. Postural activity (standing and lying) differed between animals but not between diets. During fasting, some animals occasionally excreted moderately blood-stained urine.

\section{Urinary total-nitrogen excretion in absence of protein infusion}

Total urinary- $\mathrm{N}$ excretion during the initial and final $\mathrm{N}$-free infusion periods is shown in Table 2. Since animals in groups $A$ and $C$ did not receive energy and protein during these periods, their $\mathrm{N}$ excretion values can be considered as fasting $\mathrm{N}$ excretion and they averaged 466 and $402 \mathrm{mg} / \mathrm{kg} \mathrm{W}^{0.75}$ daily respectively. When the animals in groups $\mathrm{B}$ and $\mathrm{D}$ were given no protein but received $250 \mathrm{~kJ} / \mathrm{kg} \mathrm{W}^{0.75}$ energy daily from VFA, their mean total $\mathrm{N}$ excretion values were 320 and $268 \mathrm{mg} / \mathrm{kg} \mathrm{W}^{0.75}$ daily respectively.

\section{Urinary urea-nitrogen excretion}

The mean urinary urea- $\mathrm{N}$ excretion of different groups of animals is presented in Fig. 1. When casein- $N$ was supplied in progressively increasing amounts, the additional $250 \mathrm{~kJ} / \mathrm{kg}$ $\mathrm{W}^{0.75}$ VFA given to the animals daily in group $\mathrm{B}$ had little consistent effect on urea-N excretion. From $750 \mathrm{mg} / \mathrm{kg} \mathrm{W^{0.75 }}$ to the higher levels of casein-N infusion, both VFA supplemented (group B) and unsupplemented (group A) animals showed similar increments of urea- $\mathrm{N}$ excretion. However, when casein- $\mathrm{N}$ was supplied in progressively decreasing quantity, the additional $250 \mathrm{~kJ} / \mathrm{kg} \mathrm{W}^{0.75}$ VFA given to the animals of group $\mathrm{D}$ 
Table 2. Urinary total-nitrogen excretion $\left(\mathrm{mg} / \mathrm{kg} \mathrm{W}^{0.75} \mathrm{per} d\right)$ by sheep at the beginning (Initial) and end (Final) of a period of intragastric infusion of volatile fatty acids (VFA) and/or casein*†

(Values are means of $3 \mathrm{~d}$ observation)

\begin{tabular}{lccccc}
\hline \hline Group & Animal no. & Initial & Final & Overall mean & SD \\
\hline A & 1 & 454 & 435 & & 40 \\
& 2 & 513 & 513 & 479 & 63 \\
B & Mean & 457 & 474 & & \\
& 3 & 242 & 338 & 320 & 109 \\
C & 4 & 306 & 394 & & \\
& Mean & 274 & 366 & 422 & \\
D & 5 & 446 & 268 & & 79 \\
& 6 & 527 & 447 & 345 & 269 \\
\hline
\end{tabular}

* For details of groups and infusions, see pp. 566-568.

+ Since the animals of groups $A$ and $\mathbf{C}$ did not receive any VFA, their $\mathbf{N}$ excretion can be regarded as fasting $\mathbf{N}$ excretion.

$\ddagger$ Overall mean of initial and final $\mathbf{N}$-free infusion for the given group.

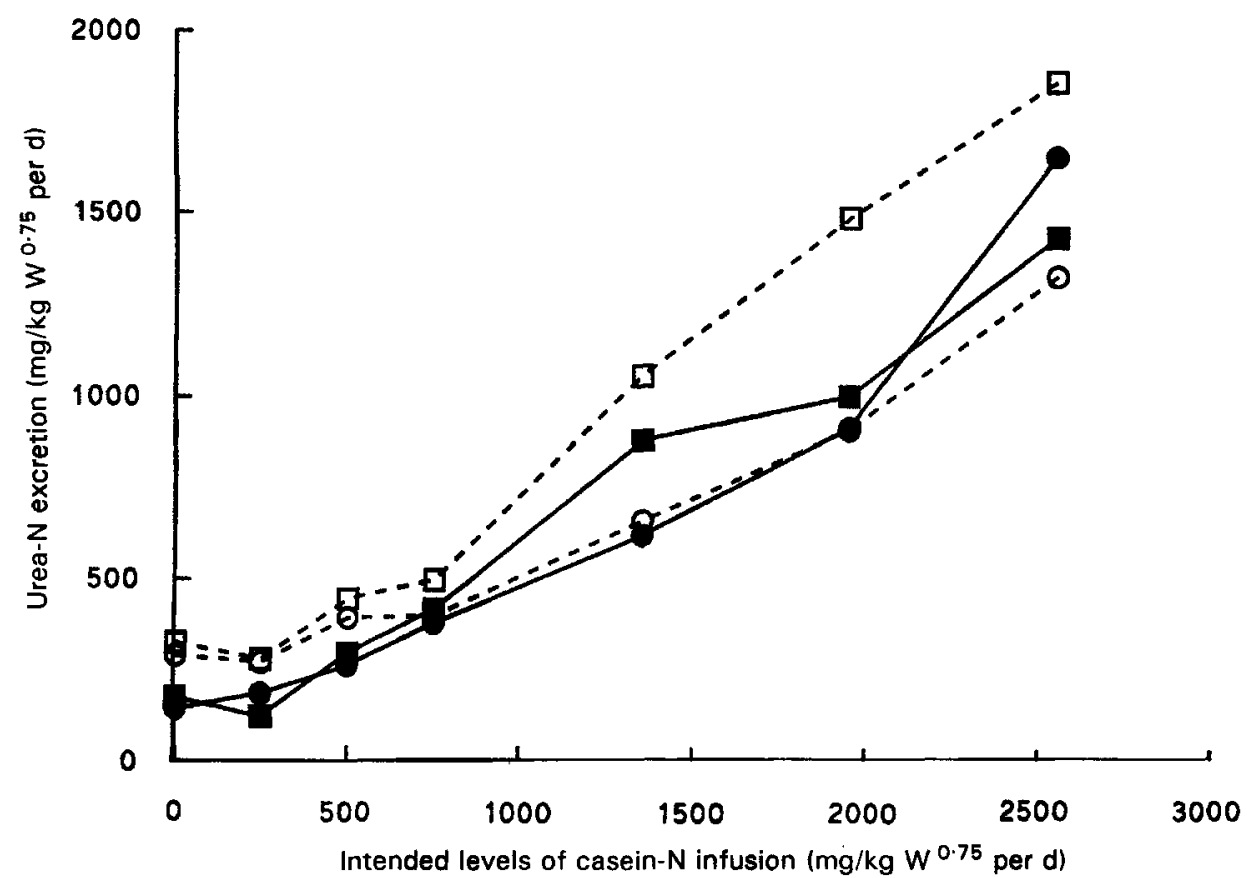

Fig. 1. Effects of different levels of casein nitrogen infusion on the urinary urea-nitrogen excretion of different groups of animals. Circles represent progressively increasing amounts of protein infusion with $(\theta)$ or without $(O) 250 \mathrm{~kJ} / \mathrm{kg}$ $\mathrm{W}^{0.75}$ per $\mathrm{d}$ of volatile fatty acids (VFA) and squares represent progressively decreasing amounts of protein infusion

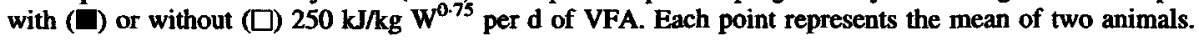



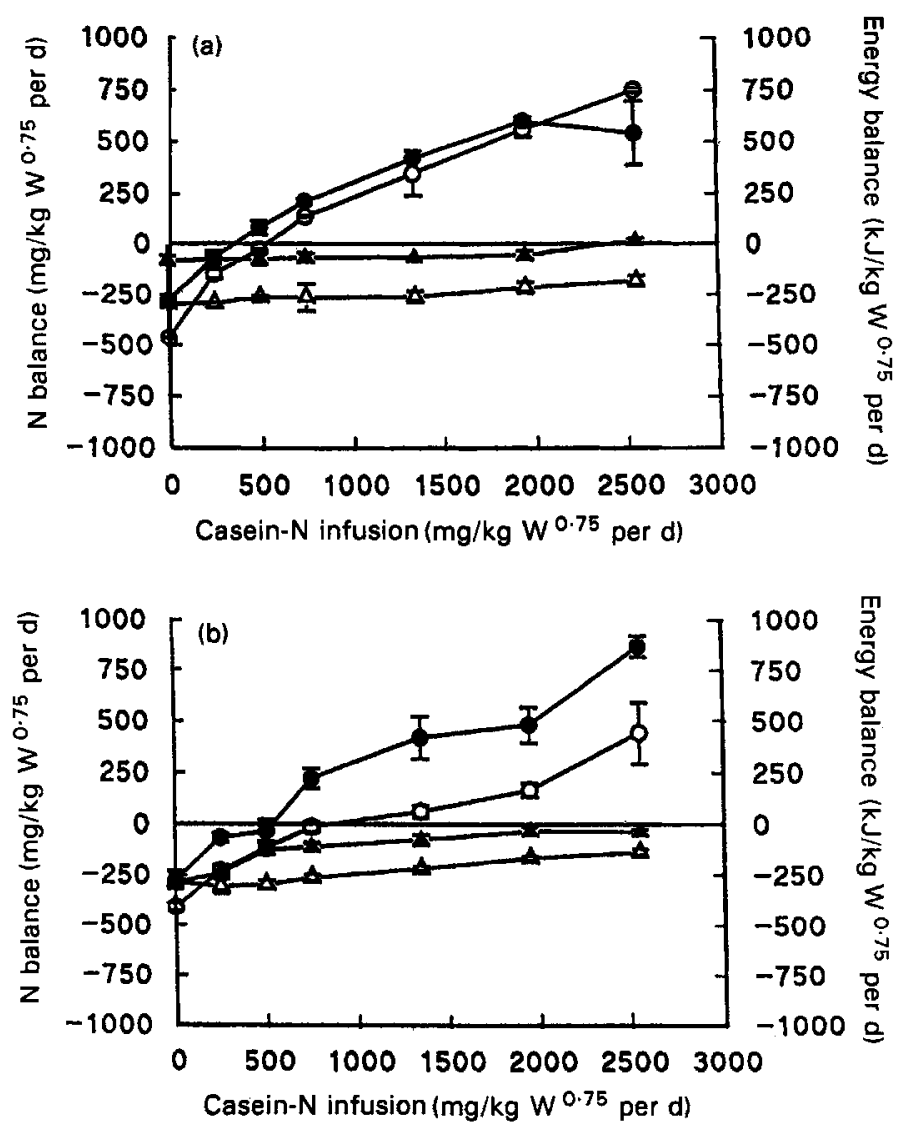

Fig. 2. Nitrogen $(\mathrm{O}, \mathrm{O})$ and energy $(\boldsymbol{\Delta}, \Delta)$ balances of lambs given progressively increasing (a) or decreasing (b) amounts of casein infusion with $(O, \Delta)$ or without $(O, \Delta) 250 \mathrm{~kJ} / \mathrm{kg} \mathrm{W} \mathbf{W}^{0.75}$ per d of energy from a mixture of volatile fatty acids. Each point represents the mean of two animals with their range as a vertical bar.

reduced urea-N excretion at all levels of casein infusion compared with that of VFAunsupplemented animals of group $\mathrm{C}$.

\section{Nitrogen and energy balance}

$\mathrm{N}$ and energy balances during progressively increasing (groups $\mathrm{A}$ and $\mathrm{B}$ ) and decreasing (groups $C$ and D) supplies of protein are shown in Figs. 2(a) and 2(b) respectively. Each point represents the mean of two animals; values from each individual animal are the mean of $3 \mathrm{~d}$ observations at each level of infusion.

Effect of supplying volatile fatty acid energy on nitrogen balance. The effect of supplying $250 \mathrm{~kJ}$ VFA/kg W $\mathrm{W}^{0.75}$ daily to the animals in groups $\mathrm{B}$ and $\mathrm{D}$ on $\mathrm{N}$ balance is shown in Figs. 2(a) and 2(b) respectively. When casein-N was infused in progressively increasing amounts, VFA addition increased the $\mathrm{N}$ balance of the animals in group $\mathrm{B}$ up to $500 \mathrm{mg} \mathrm{N} / \mathrm{kg} \mathrm{W}^{0.75}$ infusion, thereafter the effect gradually diminished from $750 \mathrm{mg} \mathrm{N} / \mathrm{kg}$ $\mathrm{W}^{0.75}$ to the higher levels of infusion. At 1950 and $2550 \mathrm{mg} \mathrm{N} / \mathrm{kg} \mathrm{W}^{0.75}$ casein-N infusion, the $\mathrm{N}$ balances were similar or even higher in the VFA-unsupplemented animals of group 
Table 3. The linear relationship between casein-nitrogen infusion (mg/kg $W^{0.75}$ per d) (independent variable, $\mathrm{X}$ ) and the nitrogen balance $\left(\mathrm{mg} / \mathrm{kg} \mathrm{W}^{0.75} \mathrm{per} d\right.$ ) (dependent variable, $\mathrm{Y})$ in sheep infused with various loads of volatile fatty acids and casein* $\dagger$

\begin{tabular}{lcccccc}
\hline \hline Group & Animal & Equation & $n \ddagger$ & SE of $Y$ estimate & $r^{2}$ & $\begin{array}{c}\text { Statistical } \\
\text { significance of } r\end{array}$ \\
\hline A & 1 & $Y=0.351$ (SE 0.021)X -206 & 6 & 44.4 & 0.89 & $P<0.01$ \\
& 2 & $Y=0.389($ SD 0.040)X -199 & 6 & 81.4 & 0.96 & $P<0.01$ \\
B & 3 & $Y=0.309($ SE 0.026)X -465 & 6 & 53.2 & 0.97 & $P<0.01$ \\
& 4 & $Y=0.344($ SE 0.034)X-115 & 6 & 70.4 & 0.96 & $P<0.01$ \\
C & 5 & $Y=0.201($ SE 0.022)X -279 & 6 & 48.0 & 0.64 & $P<0.01$ \\
& 6 & $Y=0.234($ SE 0.026)X -195 & 6 & 52.4 & 0.95 & $P<0.01$ \\
D & 7 & $Y=0.424($ SE 0.090)X -177 & 6 & 185 & 0.85 & $P<0.01$ \\
& 8 & $Y=0.356($ SE 0.028)X -137 & 6 & 56.0 & 0.97 & $P<0.01$ \\
\hline \hline
\end{tabular}

* $\mathbf{N}$ balance data from the $\mathrm{N}$-free infusion were not included.

$\dagger$ For details of procedures, see pp. 566-568.

$\ddagger$ No. of observations.

A than those in group B (see Fig. 2(a)). However, such an effect was not observed when casein- $\mathrm{N}$ was infused in progressively decreasing amounts when addition of $250 \mathrm{~kJ}$ VFA/ $\mathrm{kg} \mathrm{W}^{0.75}$ to animals in group $\mathrm{D}$ resulted in higher $\mathrm{N}$ balance at all levels of infusion compared with that of the energy unsupplemented animals of group $\mathrm{C}$ (Fig. 2(b)).

When linear regression was applied to the $N$ infusion $(X)$ and the $N$ balance $(Y)$ for the individual animals (Table 3), the slopes for the individual animals in groups A, B, and D were very similar, having a mean of 0.362 (SD 0.0396). On the other hand, $\mathrm{N}$ balance slopes for group $\mathrm{C}$ were much lower, having a mean of 0.218 .

Nitrogen balance at negative energy balance. Figs. 2(a) and 2(b) show the energy and $\mathrm{N}$ balances of groups $\mathrm{A}$ and $\mathrm{B}$ and of $\mathrm{C}$ and $\mathrm{D}$ respectively. It can be seen that all the animals were in negative energy balance (except group $B$ at $2550 \mathrm{mg} / \mathrm{kg} \mathrm{W}^{0.75}$ of $\mathrm{N}$ infusion daily) while they retained substantial amounts of $\mathbf{N}$ at higher levels of casein- $\mathbf{N}$ infusion. At the same time, the animals were in negative energy balance, equivalent to mean cumulative body fat losses of $4.03,0.90,3.52$ and $1.29 \mathrm{~kg}$ respectively for groups $\mathrm{A}$, $B, C$ and $D$. These values were calculated from their respective energy balances, divided by the energy content of fat (i.e. fat mobilized = negative energy balance/39; where 39 is the energy content (kJ) of each gram of fat (Agricultural Research Council, (1980)).

\section{Heat production}

The daily corrected (for standing) heat production values for the individual animals at different levels of infusion are presented in Table 4. Since animals of groups A and C did not receive any VFA energy, heat production during $\mathrm{N}$-free infusion can be regarded as fasting heat production. The mean initial daily fasting heat production of the animals of group A decreased from $297 \mathrm{~kJ} / \mathrm{kg} \mathrm{W}^{0.75}$ to 284,274 and $287 \mathrm{~kJ} / \mathrm{kg} \mathrm{W}^{0.75}$ when they were infused with 250,500 and $750 \mathrm{mg} / \mathrm{kg} \mathrm{W^{0.75 }}$ of casein-N. Slightly decreased heat production during $250 \mathrm{mg} / \mathrm{kg} \mathrm{W}^{0.75}$ of casein $\mathrm{N}$ infusion was also observed in one animal of group C. In groups B and D, the obvious effect of $250 \mathrm{~kJ} / \mathrm{kg} \mathrm{W}^{0.75}$ of VFA infusion daily was a higher heat production than was seen in VFA-unsupplemented animals in groups $\mathrm{A}$ and $C$ at all levels of infusion. 
S. A. CHOWDHURY ET AL.

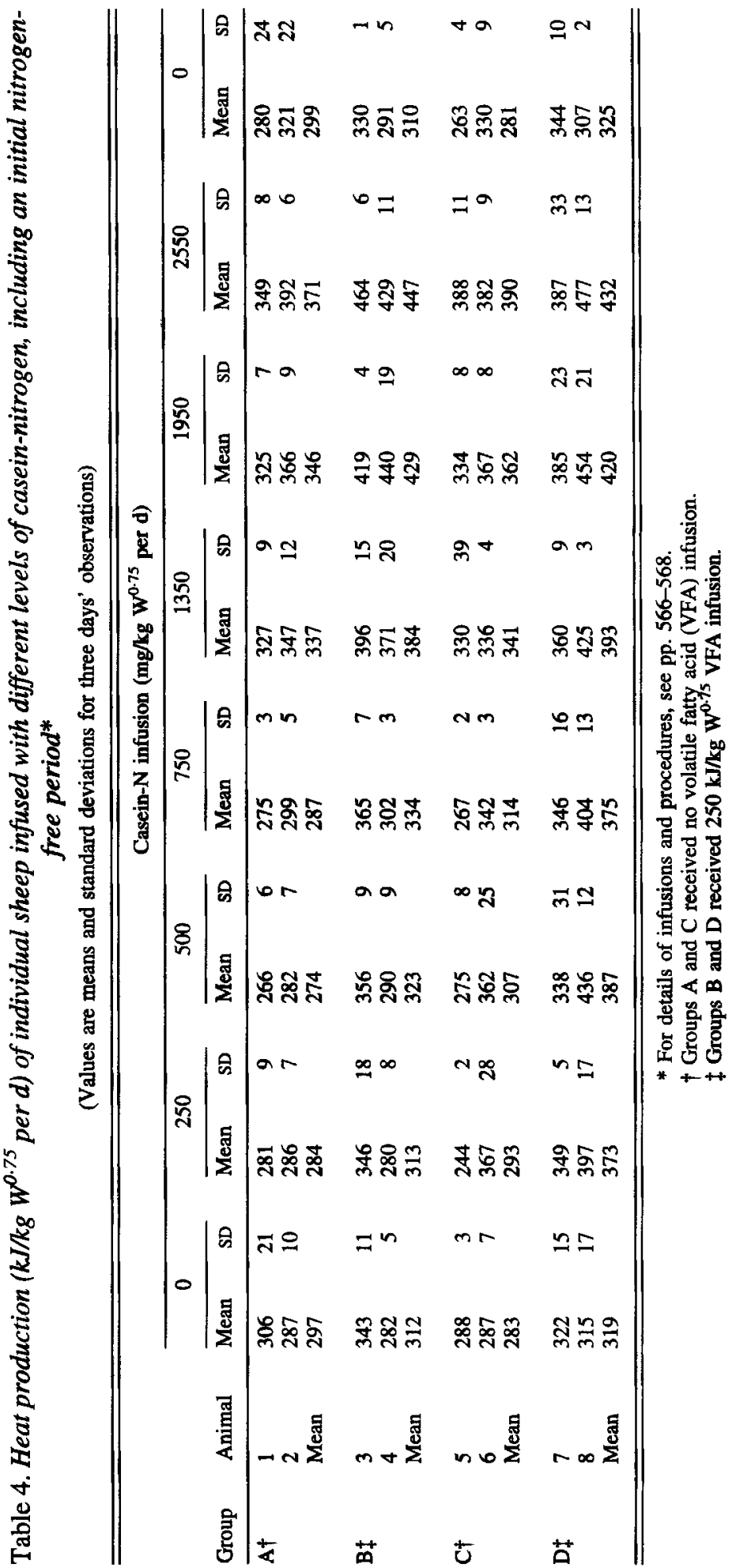




\section{DISCUSSION}

\section{Fasting nitrogen excretion}

Fasting N excretion of $402-466 \mathrm{mg} / \mathrm{kg} \mathrm{W} \mathrm{W}^{0.75}$ daily observed in the present trial is very similar to $429 \mathrm{mg} / \mathrm{kg} \mathrm{W}^{0.75}$ observed in $32 \mathrm{~kg}$ lambs nourished by intragastric nutrition by Hovell et al. (1983). These values agree with other observations on sheep but are much lower than those observed for intragastrically nourished cattle: $641 \mathrm{mg} / \mathrm{kg} \mathrm{W}^{0.75}$ (Ørskov et al. 1983), $510 \mathrm{mg} / \mathrm{kg} \mathrm{W}^{0.75}$ (Lobley et al. 1987), $616 \mathrm{mg} / \mathrm{kg} \mathrm{W}^{0.75}$ (Ku Vera, 1988) and $633 \mathrm{mg} / \mathrm{kg} \mathrm{W}^{0.75}$ (Chowdhury, 1989). It has been suggested that differences in maturity could affect the extent of protein oxidation in fasted animals (Ørskov, 1982). Indeed, daily urinary fasting $\mathrm{N}$ excretion in young immature steers was found to be higher $(727 \mathrm{mg} / \mathrm{kg}$ $\mathrm{W}^{0.75}$ ) than in mature fat steers $\left(539 \mathrm{mg} / \mathrm{kg} \mathrm{W}^{0.75}\right)(\mathrm{Ku}$ Vera, 1988).

\section{Effect of volatile fatty acid infusion on urea-nitrogen excretion}

Since urinary urea-N is an indicator of protein oxidation (Madsen, 1983), VFA infusion was expected to reduce the urea-N excretion. During progressively decreasing supplies of protein, additional VFA reduced the urea- $\mathrm{N}$ excretion probably by sparing protein oxidation. However, during progressively increasing loads of protein infusion, the effect of VFA infusion on urinary urea-N excretion was observed only up to $500 \mathrm{mg}$ casein-N/kg $\mathrm{W}^{0.75}$ but not at higher levels of infusion. At higher levels of casein infusion, the glucogenic amino acids infused may have met the metabolic glucose requirement and thus the effect of VFA supply on urea-N excretion disappeared. For example, when group A received $1950 \mathrm{mg}$ casein- $\mathrm{N} / \mathrm{kg} \mathrm{W}^{0.75}$, glucose supply estimated from the protein oxidation (obtained from urinary urea-N excretion) and fat mobilization (obtained from energy balance), (assuming $550 \mathrm{~g}$ glucose $/ \mathrm{kg}$ protein and $100 \mathrm{~g}$ glucose $/ \mathrm{kg}$ fat mobilized; Krebs, 1964) was about $70 \mathrm{~g}$ daily which is similar to the glucose turnover rate for a $45 \mathrm{~kg}$ sheep (Bergman, 1973). At that level of casein infusion, both groups (receiving and not receiving the VFA infusion) had similar urea-N excretion although the latter (group A) was in greater negative energy balance than the former (group B). It may be that during progressively increasing supplies of protein, the N-sparing effect of supplied VFA at lower levels of casein infusion was due more to glucogenic demand than the energy status of the animal. However, why the same phenomenon did not occur in the other groups of animals ( $\mathrm{C}$ and D) is not known.

\section{Nitrogen balance}

Three points are demonstrated by the results obtained for $\mathrm{N}$ balance. First, animals attained positive $\mathrm{N}$ balance when they were in negative energy balance. Second, when protein was supplied in progressively increasing amounts, additional exogenous VFA did not improve the $\mathrm{N}$ balance. Third, $\mathrm{N}$ balance increased curve-linearly with the increase in casein- $\mathrm{N}$ infusion.

The fact that animals showed rapid gains in protein while they were in negative energy balance is in agreement with the observations made in this laboratory on dairy cows (Ørskov et al. 1983), steers (Chowdhury et al. 1990) and lambs (Hovell et al. 1983). At $2550 \mathrm{mg} / \mathrm{kg} \mathrm{W}^{0.75}$ of casein-N infusion, group A retained $750 \mathrm{mg} \mathrm{N} / \mathrm{kg} \mathrm{W}^{0.75}$ daily when in energy deficit of approximately $180 \mathrm{~kJ} / \mathrm{kg} \mathrm{W}^{0.75}$. For a $45 \mathrm{~kg}$ sheep, this is equivalent to approximately $325 \mathrm{~g}$ lean-tissue gain and $100 \mathrm{~g}$ adipose-tissue loss daily (assuming that 0.2 of total $\mathrm{N}$ is retained as wool, $200 \mathrm{~g}$ protein is deposited per $\mathrm{kg}$ tissue gain and 0.2 of 
adipose tissue is water). This observation is different from the model of $\mathbf{N}$ retention in response to protein intake in ruminants proposed by Balch (1967) according to which, irrespective of protein intake, $\mathrm{N}$ retention would always be negative when energy supply is very low. From the present observation it is evident that if the protein supply at tissue level is well above the maintenance requirements even during energy restriction an animal can gain protein by oxidizing body fat to fuel the energy deficit. In human subjects, it has been suggested (Marliss et al. 1978) that lower insulin levels allow for a greater part of energy deficit to be provided from endogenous fat. In ruminants, Oldham (1984) suggested that the secretion of growth hormone and insulin-like growth factor I, under the influence of negative energy balance and the supply of exogenous amino acids, is responsible for the simultaneous protein accretion and fat oxidation. Thus, information from the present and previous studies in ruminants and non-ruminants (Fuller \& Croft, 1977; Marliss et al. 1978; Garlick et al. 1980; Winterer et al. 1980) clearly shows that body fat can be used as a source of energy to fuel protein accretion during energy undernutrition. In this situation the classical nutritional concept of dietary protein : energy ratio is therefore only meaningful when both endogenous and exogenous energy are considered.

The $\mathrm{N}$ balance of group $\mathrm{B}$ was not improved by the addition of $250 \mathrm{~kJ} \mathrm{VFA} / \mathrm{kg} \mathrm{W}^{0.75}$ over that of VFA-unsupplemented group A except at lower levels of casein-N infusion. This finding does not support the view that at a given $\mathrm{N}$ intake, $\mathrm{N}$ balance is a function of both $\mathrm{N}$ and exogenous energy intake (Balch, 1967; Agricultural Research Council, 1980). It also differs from the models of Black \& Griffiths (1975) in sheep and Campbell (1988) in pigs where, when $\mathbf{N}$ supply is insufficient, $\mathbf{N}$ balance is independent of ME intake and linearly related to the $\mathbf{N}$ intake (protein-dependent phase); when protein supply is in excess of requirement, $\mathrm{N}$ balance is unaffected by the $\mathrm{N}$ intake and is linearly related to energy intake (energy-dependent phase). A similar observation in obese subjects was made by Marliss et al. (1978), who suggested that animals have a caloristat, which enables them to quantify the exogenous energy supply and respond by mobilizing body fat to precisely fill the deficit. At lower levels of casein infusion, VFA addition improved the $\mathrm{N}$ balance in group B, presumably by sparing amino acid catabolism for gluconeogenesis. However, the buffering effects of endogenous energy were not observed in group $\mathrm{C}$ where protein was supplied in progressively decreasing amounts. From Table 3 it can be seen that, for each $\mathrm{mg}$ increase in casein- $\mathrm{N}$ infusion, the mean $\mathrm{N}$ balance increased by $0.37,0.33$ and $0.39 \mathrm{mg} / \mathrm{kg} \mathrm{W}^{\mathbf{0 . 7 5}}$ daily in groups A, B and D respectively, values which were much higher than the $0.218 \mathrm{mg} / \mathrm{kg} \mathrm{W}^{0.75}$ daily observed in group $\mathrm{C}$. Therefore, lower $\mathrm{N}$ balances in group C cannot be explained simply by the descending order of the amount of casein infused. When animals were slaughtered at the end of the experiment, the animals of group $\mathrm{C}$ were found to have a lower estimated initial body fat content $(9.9$ and $11.7 \mathrm{~kg}$; mean $10.8 \mathrm{~kg}$ ) than the animals of group A (11.9 and $11.0 \mathrm{~kg}$; mean $11.45 \mathrm{~kg})$. When the estimated initial body fat contents of the animals of groups $\mathrm{A}$ and $\mathrm{C}$ were regressed against their respective slope of the N-balance (Table 3), the following relationship was observed:

$$
Y=-0.369+0.0596(\text { SE } 0.0568) X ;\left(r^{2} 0.355 ; n 4\right) \text {, }
$$

where $X$ is the estimated initial body fat content $(\mathrm{kg})$ and $Y$ is the slope of N-balance response $\left(\mathrm{mg} / \mathrm{kg} \mathrm{W}^{0.75}\right.$ daily).

This relationship suggests that for each $\mathrm{kg}$ increase in initial body fat, the slope of $\mathrm{N}$ balance response increases by $0.0596 \mathrm{mg} / \mathrm{kg} \mathrm{W}^{0.75}$ daily, which means that, during exogenous energy restriction with adequate protein supply, the higher the body fat content of the animal, the higher will be the N-balance response. Sidhu et al. (1973) showed that the cyclic AMP activity (which reflects the potential ability of an animal to mobilize fat) is 
higher in fat than lean lambs. It may be that initial body condition can affect the lipolytic activity and thus the extent to which body fat is able to supply energy for protein retention during exogenous energy undernutrition. Since the present trial was not designed for this purpose, care should be taken in reaching any conclusion.

\section{Fasting heat production}

The reduction in fasting heat production in group A when casein was infused up to $500 \mathrm{mg} /$ $\mathrm{kg} \mathrm{W}^{0.75}$ per $\mathrm{d}$, contrasts with the well-known heat increment effect of food. The supply of exogenous amino acids might have spared the energy cost of mobilizing endogenous glucogenic precursors (amino acids and glycerol), so leading to the observed decrease in heat production, although the actual energy cost of proteolysis and lipolysis is uncertain (Lobley, 1990).

The present study shows clearly that during energy undernutrition, an adequate supply of protein enables lambs to gain lean tissue by efficient utilization of endogenous energy (presumably body fat). Evidently endogenous energy can effectively meet the energy requirements for protein accretion during energy undernutrition. The effect of submaintenance amounts of energy seems to be as much due to sparing and/or provision of glucogenic precursors as to a simple energy effect.

\section{REFERENCES}

Agricultural Research Council (1980). The Nutrient Requirements of Farm Livestock. Slough: Commonwealth Agricultural Bureaux.

Atkinson, T., Fowler, V. R., Garton, G. A. \& Lough, A. K. (1972). A rapid method for accurate determination of lipid in animal tissue. Analyst 97, 562-568.

Balch, C. C. (1967). Problems in predicting the role of non-protein nitrogen as a substitute for protein in rations for farm ruminants. World Review of Animal Production 3, 84-91.

Bergman, E. N. (1973). Glucose metabolism in ruminants as related to hypoglycemia and ketosis. Cornell Veterinarian 63, 341-382.

Black, J. L. \& Griffiths, D. A. (1975). The effect of live weight and energy intake on nitrogen balance and total nitrogen requirements of lambs. British Journal of Nutrition 33, 339-413.

Brockway, J. M. (1987). Influence of Activity. Rowett Research Institute Report. Aberdeen: Rowett Research Institute.

Campbell, R. G. (1988). Nutritional constraints to lean tissue accretion in farm animals. Nutrition Research Reviews 1, 233-253.

Chowdhury, S. A. (1989). Energy and protein metabolism during undernutrition. MSc Thesis, University of Aberdeen.

Chowdhury, S. A. (1992). Protein utilization during energy undernutrition in sheep. PhD Thesis, University of Aberdeen.

Chowdhury, S. A., Ørskov, E. R. \& MacLeod, N. A. (1990). Protein utilization during energy undernutrition in steers. Proceedings of the Nutrition Society 49, 208A

Davidson, J., Matheison, J. \& Boyne, A. W. (1970). The use of automation in determining nitrogen in Kjeldahl method with final calculation by computer. Analyst 95, 181-193.

Fuller, M. F. \& Croft, M. (1977). The protein sparing effect of carbohydrate. Nitrogen retention of the growing pig in relation to diet. British Journal of Nutrition 39, 479-488.

Garlick, P. J., Clugston, G. A. \& Waterlow, J. C. (1980). Influence of low energy diets on whole body protein turnover in obese subjects. American Joumal of Physiology 238, E235-E244.

Hovell, F. D. DeB., Ørskov, E. R., Kyle, D. \& MacLeod, N. A. (1983). Basal urinary nitrogen excretion and growth response to supplemental protein by lambs close to energy equilibrium. British Journal of Nutrition 50, $173-187$.

Krebs, H. A. (1964). The metabolic fate of amino acids. In Mammalian Protein Metabolism, pp. 125-176 [H. N. Munro and J. N. Allison, editors]. New York: Academic Press.

Ku Vera, J. C. (1988). Energy and $\mathrm{N}$ metabolism in cattle nourished by intragastric infusion of nutrients. PhD Thesis, University of Aberdeen.

Leat, W. M. F. (1983). Adipose tissue and structural lipid. In Dynamic Biochemistry of Animal Production. World Animal Science A, pp. 109-136 [P. M. Riis, editor]. Amsterdam, Oxford, New York, Tokyo: Elsevier. 
Livesey, G. (1984). The energy equivalents of ATP and the energy values of food proteins and fats. British Journal of Nutrition 51, 15-28.

Lobley, G. E. (1990). Energy metabolism reactions in ruminant muscle: response to age, nutrition and hormonal status. Reproduction Nutrition and Development 30, 13-34.

Lobley, G. E., Connell, A. \& Buchan, V. (1987). Effect of food intake on energy and protein metabolism in finishing beef steers. British Journal of Nutrition 57, 457-465.

MacLeod, N. A., Corrigal, W., Striton, R. A. \& Ørskov, E. R. (1982). Intragastric infusion of nutrients in cattle. British Journal of Nutrition 47, 547-552.

Madsen, A. (1983). The molecular basis of animal production: metabolism in liver cells. In Dynamic Biochemistry of Animal Production. World Animal Science, A, pp. 53-74 [P. M. Riis, editor]. Amsterdam, Oxford, New York, Tokyo: Elsevier.

Marliss, E. B., Murry, F. T. \& Nakhooda, A. F. (1978). The metabolic response to hypocaloric protein diets in obese man. Journal of Clinical Investigation 62, 468-479.

Oldham, J. D. (1984). Protein-energy interrelationship in dairy cows. Journal of Dairy Science 10, $1090-1114$.

Ørskov, E. R. (1982). Protein Nutrition in Ruminants. London: Academic Press.

Ørskov, E. R., Grubb, D. A., Wenham, G. \& Corrigal, W. (1979). The sustenance of growing and fattening ruminants by intragastric infusion of volatile fatty acids and protein. British Journal of Nutrition 41, 553-558.

Ørskov, E. R. \& Hovell, F. D. DeB. (1986). Protein metabolism and utilization during undernutrition in ruminants. In Nuclear and Related Techniques in Animal Production Health, pp. 429-438. Vienna: International Atomic Energy Agency.

Ørskov, E. R., MacLeod, N. A., Fahmy, S. T. M., Istasse, L. A. \& Hovell. F. D. DeB (1983). Investigation of nitrogen balance in dairy cows and steers nourished by intragastric infusion. Effect of submaintenance energy input with or without protein. British Journal of Nutrition 50, 99-107.

Sidhu, K. S., Emery, R. S., Parr, A. F. \& Merkel, R. A. (1973). Fat mobilization lipase in relation to fatness in lambs. Journal of Animal Science 36, 658-662.

Technicon Instrument Co. Ltd (1967). Technicon Autoanalyser Methodology Urea-N, Sheet no. N-1C. Terrytown: Technicon Instrument Corporation.

Winterer, J., Bistrian, B. R., Bilmazes, C., Blackburn, G. L. \& Young, V. R. (1980). Whole body protein turnover study with ${ }^{15} \mathrm{~N}$-glycine and muscle protein breakdown in mildly obese subjects during a protein sparing diet and a brief total fast. Metabolism 29, 575-581. 